\title{
Physiological quality of Urochloa brizantha seeds submitted to priming with calcium salts ${ }^{1}$
}

\author{
Elizena Cristina Gomes Ribeiro², Rodrigo de Góes Esperon Reis ${ }^{2}$, \\ Cesar Crispim Vilar ${ }^{2}$, Flavia Carolina Moreira Vilar ${ }^{2}$
}

\section{ABSTRACT}

Seed priming provides a variety of benefits, including seed invigoration and reduced dormancy. Urochloa brizantha seeds are typically primed with difficult-to-acquire potassium nitrate $\left(\mathrm{KNO}_{3}\right)$. In this sense, calcium salts stand out as an alternative, but it is important to determine whether they provide the same benefits as potassium nitrate. This study aimed to evaluate the physiological quality of $U$. brizantha seeds after priming with calcium salts, and compare the results to those obtained with potassium nitrate. Seeds were submitted to priming with calcium nitrate $\left[\mathrm{Ca}\left(\mathrm{NO}_{3}\right)_{2}\right]$ and calcium sulphate $\left(\mathrm{CaSO}_{4}\right)$ at $-0.55 \mathrm{MPa}$ and $-1.10 \mathrm{MPa}$, for $12 \mathrm{~h}$ and $24 \mathrm{~h}$, and potassium nitrate $\left(\mathrm{KNO}_{3}\right)$ at $-1.10 \mathrm{MPa}$ for $12 \mathrm{~h}$, as well as to no priming (control). A completely randomized design, with ten treatments and four repetitions, was used. Priming promoted a higher germination percentage and lower seed dormancy, with a greater seedling emergence in a shorter time period. $\mathrm{CaSO}_{4}$ did not differ from $\mathrm{KNO}_{3}$ in shoot dry weight of seedlings, but reduced the electrical conductivity of seeds. Calcium nitrate and calcium sulfate show a promising potential for use in the osmotic priming of Urochloa brizantha (BRS Piatã cultivar) seeds, since they are as efficient as potassium nitrate, as well as less costly and easier to purchase. Calcium sulfate priming at $-0.55 \mathrm{MPa}$ for $12 \mathrm{~h}$, at $25^{\circ} \mathrm{C}$, is recommended to replace the potassium nitrate solution.

KEYWORDS: Seed invigoration, calcium nitrate, calcium sulfate.

\section{INTRODUCTION}

Grasses from the Urochloa (previously Brachiaria) genus have become increasingly important in the Brazilian livestock breeding due to their use as pasture (Valle et al. 2009), accounting for about $80 \%$ of the pasture seed market (Costa et al. 2011). As such, Brazil has become the global leader

\section{RESUMO}

Qualidade fisiológica de sementes de Urochloa brizantha submetidas a condicionamento com sais de cálcio

O condicionamento fisiológico proporciona vários benefícios, como melhoria no vigor das sementes e redução no grau de dormência. Em sementes de Urochloa brizantha, geralmente, se utiliza nitrato de potássio $\left(\mathrm{KNO}_{3}\right)$, que é de difícil aquisição. Nesse sentido, os sais de cálcio se destacam, mas é necessário verificar se proporcionam os mesmos benefícios que o $\mathrm{KNO}_{3}$. Objetivou-se avaliar a qualidade fisiológica de sementes de $U$. brizantha após condicionamento com sais de cálcio, em comparação a $\mathrm{KNO}_{3}$. Utilizaram-se sementes submetidas a condicionamento fisiológico com nitrato de cálcio $\left[\mathrm{Ca}\left(\mathrm{NO}_{3}\right)_{2}\right]$ e sulfato de cálcio $\left(\mathrm{CaSO}_{4}\right)$ a $-0,55 \mathrm{MPa}$-1,10 MPa, por $12 \mathrm{~h}$ e $24 \mathrm{~h}$, além de $\mathrm{KNO}_{3} \mathrm{a}-1,10 \mathrm{MPa}$, por $12 \mathrm{~h}$, e sementes sem condicionamento (testemunha). Utilizouse delineamento inteiramente casualizado, com dez tratamentos e quatro repetições. $\mathrm{O}$ condicionamento proporcionou menor porcentagem de sementes dormentes e maior porcentagem de germinação e de emergência de plântulas em menor tempo. $\mathrm{O} \mathrm{CaSO}_{4}$ não diferiu do $\mathrm{KNO}_{3}$, quanto à massa seca da parte aérea de plântulas, e reduziu a condutividade elétrica das sementes. Nitrato e sulfato de cálcio apresentam potencial promissor para serem utilizados no condicionamento osmótico de sementes de $U$. brizantha $\mathrm{cv}$. BRS Piatã, visto que são tão eficientes quanto o $\mathrm{KNO}_{3}$, possuem menor custo e têm maior facilidade de aquisição. Recomenda-se o condicionamento em solução de sulfato de cálcio a -0,55 MPa por $12 \mathrm{~h}$, a $25^{\circ} \mathrm{C}$, para substituir a solução de nitrato de potássio.

PALAVRAS-CHAVE: Envigoramento de sementes, nitrato de cálcio, sulfato de cálcio.

in Urochloa spp. seed production, consumption and exportation (Pereira et al. 2011).

The demand for Urochloa spp. seeds has increased considerably, largely due to the use of straw in no-tillage areas, providing benefits such as higher biomass production, better soil coverage and slower decomposition, which suppress weeds and prevent re-infestation (Timossi et al. 2007, Torres et al. 2008). 
Urochloa spp. seeds do not germinate uniformly because of external structures that inhibit gas diffusion and/or lead to undeveloped embryos (Munhoz et al. 2009, Binotti et al. 2014), compromising the pasture implementation and contributing to its degradation (Lacerda et al. 2010).

Studies aimed at overcoming seed dormancy are indispensable in obtaining better quality seed lots with high germination and vigor. In this respect, pre-germination treatments such as priming may reduce the percentage of dormant seeds, accelerating germination and homogenizing the seedling establishment (Abdoli 2014, Binotti et al. 2014, Cardoso et al. 2015, Paparella et al. 2015, Gebreegziabher \& Qufa 2017, Batista et al. 2018, Pereira et al. 2018).

Priming involves the partial moistening of seeds, what helps to unlock the metabolic processes that occur during the initial germination phases, preventing radicle protrusion and maintaining seed tolerance to desiccation (Paparella et al. 2015, Ibrahim 2016). As a result, the seeds prepare for germination by restructuring membranes and reorganizing metabolic systems, what favors a faster uniform germination when conditions become more favorable, or in adverse environments (Jisha et al. 2013, Ibrahim 2016, Batista et al. 2018). Osmotic conditioning, or osmopriming, is a priming technique whereby seeds are soaked in a solution with low hydric potential, and water absorption occurs until their internal hydric potential and that of the solution are the same (Jisha et al. 2013, Hussian et al. 2014).

According to the scientific literature on seed priming, potassium nitrate $\left(\mathrm{KNO}_{3}\right)$ has shown promising results in improving the physiological quality of several species (Anosheh et al. 2011, Entesari et al. 2012), including Urochloa brizantha (Bonome et al. 2006, Binotti et al. 2014, Cardoso et al. 2015). In addition to osmotic priming, most studies use other substances to boost seed germination and seedling establishment in the field, including nutrients, growth regulators and biostimulants (Cardoso et al. 2015, Ramos et al. 2015, Pallaoro et al. 2016, Batista et al. 2018).

Calcium salts such as calcium nitrate $\left[\mathrm{Ca}\left(\mathrm{NO}_{3}\right)_{2}\right]$ and calcium sulfate $\left(\mathrm{CaSO}_{4}\right)$ are an alternative to $\mathrm{KNO}_{3}$, can be easily purchased and are less costly. Studies have found that priming using nitrates overcomes dormancy and increases germination, since they act as oxidants, converting
$\mathrm{NAD}(\mathrm{P}) \mathrm{H}$ to $\mathrm{NAD}(\mathrm{P})^{+}$in the pentose-phosphate metabolic pathway (Hendricks \& Taylorson 1974, Cardoso et al. 2015). In the case of calcium sulfate, studies have shown accelerated emergence and decreased mortality in seeds planted in acidic soil (Murata et al. 2008), likely due to the immobilization of $\mathrm{Al}^{3+}$, the main problem in these soils.

This study aimed to evaluate the physiological quality of Urochloa brizantha (BRS Piatã cultivar) seeds after priming with calcium salts, and compare the results to those obtained with potassium nitrate priming.

\section{MATERIAL AND METHODS}

The experiment was carried out at the Universidade do Estado de Mato Grosso, in Nova Xavantina, Mato Grosso state, Brazil, from October to December 2016. The Urochloa brizantha (BRS Piatã cultivar) seeds were harvested in the 2015/2016 season.

Each treatment consisted of $20 \mathrm{~g}$ of seeds submitted to priming at $25^{\circ} \mathrm{C}$, in solutions of calcium nitrate $\left[\mathrm{Ca}\left(\mathrm{NO}_{3}\right)_{2}\right]$ and calcium sulfate $\left(\mathrm{CaSO}_{4}\right)$, at $-0.55 \mathrm{MPa}$ and $-1.10 \mathrm{MPa}$, for $12 \mathrm{~h}$ and $24 \mathrm{~h}$, and a potassium nitrate $\left(\mathrm{KNO}_{3}\right)$ solution at $-1.10 \mathrm{MPa}$ for $12 \mathrm{~h}$ (Bonome et al. 2006), as well as no priming (control). Each solution was prepared using the concentrations presented in Table 1, in order to obtain the desired osmotic potential.

The concentration of all solutions containing calcium salts and potassium nitrate were calculated using the Van't Hoff's equation (Hillel 1971): $\Psi_{\text {os }}=-$-iRTC, where $\Psi_{\text {os }}$ is the osmotic potential of the solution $(\mathrm{MPa}), \mathrm{i}$ the isotonic coefficient, $\mathrm{R}$ the gas constant $\left(0.0083 \mathrm{~L} \mathrm{MPa} \mathrm{K}^{-1} \mathrm{~mol}^{-1}\right)$, $\mathrm{T}$ the temperature $(\mathrm{K})$ and $\mathrm{C}$ the concentration $\left(\mathrm{mol} \mathrm{L}^{-1}\right)$.

The following equation was used to calculate the isotonic coefficient (i): $i=1+\alpha(q-1)$, where $\alpha$ is the degree of ionization (decimal) and $\mathrm{q}$ the total

Table 1. Solutes, osmotic potential and concentrations of solutions used for osmotic priming of Urochloa brizantha (BRS Piatã cultivar) seeds.

\begin{tabular}{lcc}
\hline Solute & $\begin{array}{c}\text { Osmotic potential } \\
\text { at } 25^{\circ} \mathrm{C}(\mathrm{MPa})\end{array}$ & $\begin{array}{c}\text { Concentration } \\
\left(\mathrm{g} \mathrm{L}^{-1}\right)\end{array}$ \\
\hline $\mathrm{Ca}\left(\mathrm{NO}_{3}\right)_{2} 4 \mathrm{H}_{2} \mathrm{O}$ & -0.55 & 17.5568 \\
\cline { 2 - 3 } & -1.10 & 35.1276 \\
\hline $\mathrm{CaSO}_{4} 2 \mathrm{H}_{2} \mathrm{O}$ & -0.55 & 19.1816 \\
\hline $\mathrm{KNO}_{3}$ & -1.10 & 38.3910 \\
\hline
\end{tabular}


number of ions released during the ionization of a compound (mol).

Seeds from each treatment $(20 \mathrm{~g})$ were placed in $500 \mathrm{~mL}$ plastic containers to which $150 \mathrm{~mL}$ of priming solution were added in order to cover all the seeds. The control seeds did not receive any pre-treatment.

In order to prevent seed anoxia, all the solutions were aerated using silicone hoses connected to an aquarium compressor (MINJINAG, NS 750). After priming, the seeds were washed under running water for $5 \mathrm{~min}$ and dried at room temperature $\left(\approx 25^{\circ} \mathrm{C}\right)$ for $48 \mathrm{~h}$, with a final moisture similar to the initial moisture content of $9 \%$ (wet basis - wb).

The following tests were used to evaluate the seed physiological quality:

Seed moisture - measured after priming and drying, in triplicate, with $0.5 \mathrm{~g}$ of seeds per treatment placed in aluminum capsules and dried in an oven (ODONTOBRÁS, EL-1.4) at $105^{\circ} \mathrm{C}$, for $24 \mathrm{~h}$. The moisture content was expressed in percentage (wb) (Brasil 2009);

Germination - quadruplicates of 50 seeds were planted in plastic germination boxes (gerbox) containing two sheets of blotting paper moistened with $14 \mathrm{~mL}$ of distilled water, and kept in a BOD incubator (ELETROlab, EL202/4) with temperatures alternating between $20^{\circ} \mathrm{C}$ and $35^{\circ} \mathrm{C}$ and photoperiod of $8 \mathrm{~h}$. The germinated seeds were counted at 7,14 and 21 days after planting (DAP), and germination percentages calculated after the first (7 DAP) and last (21 DAP) countings (Brasil 2009). Next, the nongerminated seeds were submitted to a tetrazolium test $\left(0.1 \%\right.$, at $37^{\circ} \mathrm{C}$, for $\left.4 \mathrm{~h}\right)$ to check the percentage of dormant seeds (Brasil 2009);
Emergence - quadruplicates of 50 seeds were planted in sand beds, with daily irrigation and counting of emerged seedlings until 21 DAP, when counting stabilized. The emergence percentage and average emergence time were calculated based on the values obtained at counting (Labouriau 1983). Next, the emerged seedlings were cut at the ground level, placed in paper bags and dried in a ventilated oven (SOLAB, SL-102) at $65{ }^{\circ} \mathrm{C}$, until constant weight, when the shoot dry weight was calculated. This result was then divided by 50 (initial number of seeds) to estimate the seedling vigor [mg $(50 \text { seeds })^{-1}$ ] for each replicate;

Electrical conductivity - quadruplicates of $0.5 \mathrm{~g}$ of seeds were immersed in $25 \mathrm{~mL}$ of distilled water and submitted to a temperature of $25^{\circ} \mathrm{C}$, for $24 \mathrm{~h}$. Next, the electrical conductivity $\left(\mu \mathrm{S} \mathrm{cm}^{-1} \mathrm{~g}^{-1}\right)$ of the solution was measured using a conductivity meter (DIGIMED, DM 3).

Data were submitted to analysis of variance (Anova), according to a completely randomized design, with 10 treatments and four repetitions. When the F-test was significant $(\mathrm{p} \leq 0.05)$ for the treatment effects, the means were compared by the Scott-Knott test $(p=0.05)$.

\section{RESULTS AND DISCUSSION}

The physiologically primed $U$. brizantha seeds reached between $26.5 \%$ and $31.6 \%$ of moisture, considering all priming treatments, while the control seeds exhibited $8.7 \%$ of moisture (Table 2 ).

During the physiological priming treatments, it is vital that seeds achieve moisture levels capable of initiating the preliminary germination, while

Table 2. Moisture of Urochloa brizantha (BRS Piatã cultivar) seeds submitted to osmotic priming with different salts, at two osmotic potentials for two time periods, and control (without priming), shortly after priming and after $48 \mathrm{~h}$ of drying.

\begin{tabular}{|c|c|c|c|c|}
\hline \multirow{2}{*}{ Salt } & \multirow{2}{*}{ Osmotic potential (MPa) } & \multirow{2}{*}{ Time period (h) } & \multicolumn{2}{|c|}{ Moisture (\%) } \\
\hline & & & Shortly after priming & After $48 \mathrm{~h}$ of drying \\
\hline \multirow{4}{*}{$\mathrm{Ca}\left(\mathrm{NO}_{3}\right)_{2}$} & \multirow{2}{*}{-0.55} & 12 & 28.9 & 8.9 \\
\hline & & 24 & 29.3 & 8.9 \\
\hline & \multirow{2}{*}{-1.10} & 12 & 26.5 & 9.0 \\
\hline & & 24 & 29.3 & 8.7 \\
\hline \multirow{4}{*}{$\mathrm{CaSO}_{4}$} & \multirow{2}{*}{-0.55} & 12 & 27.3 & 9.3 \\
\hline & & 24 & 31.6 & 8.9 \\
\hline & \multirow{2}{*}{-1.10} & 12 & 28.2 & 8.9 \\
\hline & & 24 & 30.9 & 8.9 \\
\hline $\mathrm{KNO}_{3}$ & -1.10 & 12 & 29.1 & 8.4 \\
\hline Control & & & 8.7 & 8.7 \\
\hline
\end{tabular}


avoiding radicle protrusion. The membrane repair, initial digestion of reserves and translocation to the embryonic axis occur during this period (Santos et al. 2008, Varier et al. 2010). However, since water absorption is limited by the osmotic potential of the solution, the vigor of the lot can be homogenized to allow less vigorous seeds to catch up with their more vigorous counterparts during the phase 2 of germination, making germination faster and more uniform when conditions become favorable.

Seeds returned to their initial moisture content after drying, varying between $8.4 \%$ and $9.3 \%$ (Table 2). Thus, the water absorbed during priming was extracted and did not influence the results of the subsequent tests, leaving only the effects of treatments, which were determined next.

All the priming treatments exhibited germination percentages significantly higher than that of the control (Table 3), which obtained germination below $40 \%$. Although there was no difference between the priming treatments, their superiority to the control illustrates one of the advantages of priming, namely an increase in the germination percentage.

Different results have been reported for other $U$. brizantha cultivars. MG-5 did not differ from the control when submitted to priming with $\mathrm{KNO}_{3}$ and $\mathrm{Ca}\left(\mathrm{NO}_{3}\right)_{2}$, displaying germination percentages between $83 \%$ and $87 \%$ (Batista et al. 2015). With respect to the priming period for 'Marandu' seeds, germination declined, but treatments did not differ significantly from the control, even after $12 \mathrm{~h}$ (Bonome et al. 2006).

The seeds that did not germinate were submitted to the tetrazolium test to assess their viability within each treatment. Based on the results, it can be inferred that primed seeds exhibited a higher germination percentage due to the lower percentage of dormant seeds, with controls displaying around $16 \%$ of dormant seeds, if compared to an average of $7 \%$ in the other treatments (Table 3 ). Similar results were presented by Batista et al. (2016), especially for priming with $\mathrm{KNO}_{3}$ and $\mathrm{Ca}\left(\mathrm{NO}_{3}\right)_{2}$.

Some studies have reported that the use of nitrates in priming overcomes dormancy and increases germination because they act as oxidants, converting $\mathrm{NAD}(\mathrm{P}) \mathrm{H}$ to $\mathrm{NAD}(\mathrm{P})^{+}$in the pentosephosphate metabolic pathway (Hendricks \& Taylorson 1974, Cardoso et al. 2015).

The treatments showed a significant effect for emergence percentage (Table 3 ), where priming with $\mathrm{Ca}\left(\mathrm{NO}_{3}\right)_{2}$ at $-0.55 \mathrm{MPa}$ for both periods $(12 \mathrm{~h}$ and $24 \mathrm{~h}$ ), as well as $\mathrm{CaSO}_{4}$ at $-0.55 \mathrm{MPa}$ for $12 \mathrm{~h}$ and $-1.10 \mathrm{MPa}$ in both periods did not differ, albeit with higher means than the other treatments, including $\mathrm{KNO}_{3}$ and the control.

Similar results were observed for MG-5 seeds primed with $\mathrm{Ca}\left(\mathrm{NO}_{3}\right)_{2}$ and $\mathrm{KNO}_{3}$, which exhibited a higher emergence percentage (Batista et al. 2016). It is noteworthy that seed vigor is related to the ability to germinate and/or emerge under adverse conditions, resulting in a fast uniform seedling establishment in the field, where the strongest effects of priming are observed.

Considering the average emergence time of seedlings (Table 3 ), the control plants needed more time to reach a maximum emergence, with an average of 5.2 days. However, they did not differ significantly from the two calcium priming solutions

Table 3. Percentage of germination (G), dormant seeds (D) and emergence (E), average emergence time (AET), shoot dry weight (SDW) and seed electrical conductivity (EC) of Urochloa brizantha (BRS Piatã cultivar) seeds submitted to osmotic priming with different salts, at two osmotic potentials, for two time periods, and control (without priming).

\begin{tabular}{|c|c|c|c|c|c|c|c|c|}
\hline \multirow{2}{*}{ Salt } & Osmotic potential & Time period & $\mathrm{G}$ & $\mathrm{D}$ & $\mathrm{E}$ & AET & SDW & $\mathrm{EC}$ \\
\hline & $\mathrm{MPa}$ & $\mathrm{h}$ & & $\%$ & $\bar{z}$ & days & mg 50 seeds $^{-1}$ & $\mu \mathrm{S} \mathrm{cm}^{-1} \mathrm{~g}^{-1}$ \\
\hline \multirow{4}{*}{$\mathrm{Ca}\left(\mathrm{NO}_{3}\right)_{2}$} & \multirow{2}{*}{-0.55} & 12 & $52 a^{*}$ & $8 \mathrm{~b}$ & $66 \mathrm{a}$ & $4.2 \mathrm{~b}$ & $7.0 \mathrm{~b}$ & $65.15 \mathrm{e}$ \\
\hline & & 24 & $50 \mathrm{a}$ & $8 \mathrm{~b}$ & $63 \mathrm{a}$ & $4.4 \mathrm{~b}$ & $7.2 \mathrm{~b}$ & $79.05 \mathrm{~d}$ \\
\hline & \multirow{2}{*}{-1.10} & 12 & $48 \mathrm{a}$ & $6 \mathrm{~b}$ & $61 \mathrm{~b}$ & $4.6 \mathrm{~b}$ & $6.3 \mathrm{~b}$ & $101.64 \mathrm{c}$ \\
\hline & & 24 & $53 \mathrm{a}$ & $5 \mathrm{~b}$ & $58 \mathrm{~b}$ & $4.8 \mathrm{a}$ & $8.8 \mathrm{a}$ & $108.92 \mathrm{~b}$ \\
\hline \multirow{4}{*}{$\mathrm{CaSO}_{4}$} & \multirow{2}{*}{-0.55} & 12 & $48 \mathrm{a}$ & $8 \mathrm{~b}$ & $65 \mathrm{a}$ & $4.4 \mathrm{~b}$ & $11.4 \mathrm{a}$ & $56.96 \mathrm{e}$ \\
\hline & & 24 & $46 \mathrm{a}$ & $8 \mathrm{~b}$ & $57 \mathrm{~b}$ & $4.4 \mathrm{~b}$ & $10.2 \mathrm{a}$ & $105.74 \mathrm{~b}$ \\
\hline & \multirow{2}{*}{-1.10} & 12 & $53 \mathrm{a}$ & $9 \mathrm{~b}$ & $70 \mathrm{a}$ & $4.4 \mathrm{~b}$ & $10.1 \mathrm{a}$ & $60.55 \mathrm{e}$ \\
\hline & & 24 & $50 \mathrm{a}$ & $6 \mathrm{~b}$ & $68 \mathrm{a}$ & $4.8 \mathrm{a}$ & $8.6 \mathrm{a}$ & $64.20 \mathrm{e}$ \\
\hline $\mathrm{KNO}_{3}$ & -1.10 & 12 & $53 \mathrm{a}$ & $5 \mathrm{~b}$ & $59 \mathrm{~b}$ & $4.3 \mathrm{~b}$ & $9.5 \mathrm{a}$ & $121.46 \mathrm{a}$ \\
\hline Control & & & $36 \mathrm{~b}$ & $16 \mathrm{a}$ & $55 \mathrm{~b}$ & $5.2 \mathrm{a}$ & $7.3 \mathrm{~b}$ & $89.16 \mathrm{c}$ \\
\hline
\end{tabular}


with $-1.10 \mathrm{MPa}$ applied for $24 \mathrm{~h}$, with an average emergence time of 4.8 days. Subsequent priming treatments with calcium salts achieved a maximum emergence in less time, with average emergence times between 4.2 and 4.6 days. Although the differences were small, it is important to underscore that seed vigor is more significant and evident under adverse conditions.

With respect to shoot dry weight (Table 3), all the $\mathrm{CaSO}_{4}$ treatments displayed higher means and did not differ from the treatments with $\mathrm{KNO}_{3}$ and $\mathrm{Ca}\left(\mathrm{NO}_{3}\right)_{2}$ at $-1.10 \mathrm{MPa}$ for $24 \mathrm{~h}$. The remaining treatments, including the control, did not differ and produced seedlings with less dry biomass.

In electrical conductivity measurements (Table 3), seeds primed with $\mathrm{KNO}_{3}$ obtained a higher mean value $\left(121.46 \mu \mathrm{S} \mathrm{cm}^{-1} \mathrm{~g}^{-1}\right)$, when compared to the other treatments. Controls exhibited intermediate values, with an average of $89.16 \mu \mathrm{S} \mathrm{cm}^{-1} \mathrm{~g}^{-1}$. The decreased osmotic potential of the solution (higher salt concentration), when the priming period increased from $12 \mathrm{~h}$ to $24 \mathrm{~h}$, was followed by a rise in the electrical conductivity of seeds primed with $\mathrm{Ca}\left(\mathrm{NO}_{3}\right)_{2}$. Lower mean values were observed when $\mathrm{CaSO}_{4}$ was used, except for an osmotic potential of $-0.55 \mathrm{MPa}$ applied for $24 \mathrm{~h}$. The highest mean values were recorded for $\mathrm{KNO}_{3}$. This can be attributed to the salt residue remaining on and inside the seeds after washing, which may have raised the electrical conductivity.

In light of these results, priming using a $\mathrm{CaSO}_{4}$ solution at $-0.55 \mathrm{MPa}$ for $12 \mathrm{~h}$ can be recommended as a replacement for $\mathrm{KNO}_{3}$, since germination and dormant seed percentages were similar to those produced by $\mathrm{KNO}_{3}$, while the shoot dry weight and electrical conductivity exhibited better results. Additionally, the $\mathrm{CaSO}_{4}$ solution at $-0.55 \mathrm{MPa}$ for $12 \mathrm{~h}$ also resulted in shorter germination times and required less material.

\section{CONCLUSIONS}

1. Calcium nitrate and calcium sulfate show a significant potential for use in the osmotic priming of Urochloa brizantha (BRS Piatã cultivar) seeds, since they are as efficient as potassium nitrate, less costly and easier to purchase;

2. Priming using a calcium sulfate solution at $-0.55 \mathrm{MPa}$ for $12 \mathrm{~h}$, at $25^{\circ} \mathrm{C}$, is recommended as a replacement for potassium nitrate.

\section{ACKNOWLEDGMENTS}

The authors would like to thank the Boa Forma Sementes, for donating the seeds used; and Fundação de Amparo à Pesquisa do Estado de Mato Grosso (Fapemat), for the funding provided.

\section{REFERENCES}

ABDOLI, M. Effect of seed priming on seed dormancy, vigor and seedling characteristics of fennel (Foeniculum vulgare L.). Acta Advances in Agricultural Sciences, v. 2, n. 8, p. 18-24, 2014.

ANOSHEH, H. P.; SADGHI, H.; EMAM, Y. Chemical priming with urea and $\mathrm{KNO}_{3}$ enhances maize hybrid (Zea mays L.) seed viability under abiotic stress. Journal of Crop Science and Biotechnology, v. 14, n. 4, p. 289-295, 2011.

BATISTA, T. B. et al. Nutrientes e giberelina no condicionamento fisiológico sob a qualidade de sementes de braquiária. Revista de Agricultura Neotropical, v. 2, n. 1, p. 10-16, 2015.

BATISTA, T. B. et al. Priming and stress under high humidity and temperature on the physiological quality of Brachiaria brizantha cv. MG-5 seeds. Acta Scientiarum Agronomy, v. 38, n. 1, p. 123-127, 2016.

BATISTA, T. B. et al. Priming of brachiaria seeds with different sugar sources and concentrations. Revista Caatinga, v. 31, n. 4, p. 843-849, 2018.

BINOTTI, F. F. S. et al. Tratamentos pré-germinativos em sementes de Brachiaria. Revista Brasileira de Ciências Agrárias, v. 9, n. 4, p. 1-5, 2014.

BONOME, L. T. S. et al. Efeito do condicionamento osmótico em sementes de Brachiaria brizantha cv. Marandu. Ciência e Agrotecnologia, v. 30, n. 3, p. 422428, 2006.

BRASIL. Ministério da Agricultura, Pecuária e Abastecimento. Regras para análise de sementes. Brasília, DF: MAPA/ACS, 2009.

CARDOSO, E. D. et al. Qualidade fisiológica e composição química de sementes de Brachiaria brizantha em função do condicionamento osmótico. Revista de Agricultura Neotropical, v. 2, n. 2, p. 42-48, 2015.

COSTA, C. J.; ARAÚJO, R. B.; VILLAS BÔAS, H. D. C. Tratamentos para superação de dormência em sementes de Brachiaria humidicola (Rendle) Schweick. Pesquisa Agropecuária Tropical, v. 41, n. 4, p. 519-524, 2011.

ENTESARI, M. et al. Effect of seed priming on mung been (Vigna radiata) cultivars with salicylic acid and potassium 
nitrate under salinity stress. International Journal of Agriculture: Research and Review, v. 2, special issue, p. 926-932, 2012.

GeBreegziabHeR, B. G.; QUFA, C. A. Plant physiological stimulation by seeds salt priming in maize (Zea mays): prospect for salt tolerance. African Journal of Biotechnology, v. 16, n. 5, p. 209-223, 2017.

HENDRICKS, S. B.; TAYLORSON, R. B. Promotion of seed germination by nitrate, nitrite, hydroxylamine, and ammonium salts. Plant Physiology, v. 54, n. 3, p. 304309, 1974.

HILLEL, D. Soil and water: physical principles and processes. New York: Academic Press, 1971.

HUSSIAN, I. et al. Seed priming: a tool to invigorate the seeds. Scientia Agriculturae, v. 7, n. 3, p. 122-128, 2014.

IBRAHIM, E. A. Seed priming to alleviate salinity stress in germinating seeds. Journal of Plant Physiology, v. 192, n. 1, p. 38-46, 2016.

JISHA, K. C.; VIJAYAKUMARI, K.; PUTHUR, J. T. Seed priming for abiotic stress tolerance: an overview. Acta Physiologiae Palntarum, v. 35, n. 5, p. 1381-1396, 2013.

LABOURIAU, L. G. A germinação das sementes. Washington, DC: OEA, 1983.

LACERDA, M. J. R. et al. Superação da dormência de Brachiaria brizantha cv. "Marandu". Semina: Ciências Agrárias, v. 31, n. 4, p. 823-828, 2010.

MUNHOZ, R. E. F.; ZONETTI, P. C.; ROMAN, S. Superação da dormência em sementes e desenvolvimento inicial em Brachiaria brizantha cv MG5 através da escarificação com ácido sulfúrico. Revista em Agronegócios e Meio Ambiente, v. 2, n. 1, p. 55-67, 2009.

MURATA, M. R.; ZHARARE, G. E.; HAMMES, P. $\mathrm{S}$. Pelleting or priming seed with calcium improves groundnut seedling survival in acid soils. Journal of Plant Nutrition, v. 31, n. 10, p. 1736-1745, 2008.

PALLAORO, D. S. et al. Priming corn seeds with plant growth regulator. Journal of Seed Science, v. 38, n. 3, p. 227-232, 2016.

PAPARELLA, S. et al. Seed priming: state of the art and new perspectives. Plant Cell Reports, v. 34, n. 8, p. 12811293, 2015.

PEREIRA, C. E. et al. Armazenamento de sementes de braquiária peletizadas e tratadas com fungicida e inseticida. Ciência Rural, v. 41, n. 12, p. 2060-2065, 2011.

PEREIRA, S. E. et al. Priming of Urochloa brizantha cv. Xaraés seeds. African Journal of Agricultural Research, v. 13, n. 49, p. 2804-2807, 2018.

RAMOS, A. R. et al. Bioestimulante no condicionamento fisiológico e tratamento de sementes de feijão. Revista Biociências, v. 21, n. 1, p. 76-88, 2015.

SANTOS, M. C. A. et al. Condicionamento osmótico de sementes. Revista Caatinga, v. 21, n. 2, p. 1-6, 2008.

TIMOSSI, P. C.; DURIGAN, J. C.; LEITE, G. J. Formação de palhada por braquiárias para adoção do sistema plantio direto. Bragantia, v. 66, n. 4, p. 617-622, 2007.

TORRES, J. L. R.; PEREIRA, M. G.; FABIAN, A. J. Produção de fitomassa por plantas de cobertura e mineralização de seus resíduos em plantio direto. Pesquisa Agropecuária Brasileira, v. 43, n. 3, p. 421-428, 2008.

VALLE, C. B.; JANK, L.; RESENDE, R. M. S. O melhoramento de forrageiras tropicais no Brasil. Revista Ceres, v. 56, n. 4, p. 460-472, 2009.

VARIER, A.; VARI, A. K.; DADLANI, M. The subcellular basis of seed priming. Current Science, v. 99, n. 4, p. 450-456, 2010. 